Хитра О. В., к.е.н., доцент Хмельнищький університет управління та права імені Леоніда Юзькова м. Хмельницький, Украйна

DOI: https://doi.org/10.30525/978-9934-26-068-1-7

\title{
СИНЕРГЕТИЧНА ІНТЕРПРЕТАЦІЯ ПРОЦЕСІВ СТАНОВЛЕННЯ І РОЗВИТКУ ТУРИСТИЧНО-РЕКРЕАЦЙННИ СИСТЕМ
}

Туристично-рекреаційна система $є$ сукупністю взаємодіючих структур, елементів i явищ, які направлені на забезпечення туристських і рекреаційних потреб суспільства. Водночас, це сукупність територіальних мереж підприємств різних субгалузей туристичного господарства, що володіють не лише інтегральними, а й власними закономірностями розміщення та розвитку з погляду територіальної диференціації економіки [1, с. 53-54].

Усі компоненти туристично-рекреаційного потенціалу (природна, економічна, соціальна) є відносно автономними, однак утворюють між собою стійкі взаємозв' язки та $є$ взаємозалежними 
в межах туристично-рекреаційних систем і дестинацій [2, с. 14]. Принциповим є те, що дії кожного із суб'єктів впливають на поведінку інших суб'єктів, однак жоден 3 них не може контролювати функціонування цілісності системи [3, с. 90-91]. Відповідно, цій системі властива емерджентність, яка проявляється у виникненні нових структур, властивостей або моделей поведінки на макрорівні (туристично-рекреаційна галузь), що $є$ результатом взаємодії елементів системи на мікрорівні (з одного боку - рекреаційні потреби і мотивація щодо подорожей різних груп туристів, з іншого - стратегії суб'єктів, які співпрацюють та/або конкурують на туристичному ринку).

Для забезпечення емерджентності, як передумови ефекту синергізму, необхідно когерентно сполучити елементи системи, синхронізувати темпи еволюції підсистем природного і антропогенного походження. У цьому контексті цілком погоджуємось 3 точкою зору І.Б. Дегтярьової, О.І. Мельник, А.В. Бондаря, що «еколого-економічні системи є надзвичайно складними динамічними утвореннями, що перебувають у стані внутрішньої рівноваги тільки за умови підтримання балансу між асиміляційним потенціалом природного середовища та антропогенним навантаженням» [4, с. 34]. Як стверджує В.В. Якімцов, усі природні та виробничо-соціально-економічні складові людської життєдіяльності є настільки взаємопов'язаними, що будь-який вплив на ту чи іншу природну компоненту призводить до непередбачуваних наслідків [5, с. 123]. Тому при розробці стратегії розвитку складних систем доцільно враховувати синергетизм коеволюційної взаємодії природного середовища і антропогенних систем, вплив стану середовища на результати господарської діяльності підприємств [6, с. 102-103].

Отже, пропонуємо розглядати туристично-рекреаційну сферу як складну соціо-еколого-економічну систему з ознаками синергетичності, що означає здатність за рахунок взаємодії внутрішніх структурних якостей 3 потоками, що надходять ззовні, до створення структурно та інформаційно матеріалізованої нової якості. Ця система має певну ієрархію: на макрорівні йдеться про 
цілісність туристично-рекреаційної галузі в масштабах національної економіки, на мезорівні досліджується самодостатність та унікальність окремих туристично-рекреаційних районів, на мікрорівні спостерігається стратегічна організованість окремих туристичних підприємств і певна хаотичність поведінки окремих туристів (рекреантів).

Важливу роль у розвитку туристично-рекреаційної системи відіграє самоорганізація, яка описується у вигляді процесів виникнення впорядкованих просторово-часових структур, що містяться у далеких від рівноваги станах поблизу точок біфуркації, де поведінка системи стає нестійкою, незрівноваженою, такою, що може різко змінити свій стан [7, с. 18].

На розвиток туристично-рекреаційної системи впливає велика кількість чинників, які, переплітаючись, формують флуктуаційний фон, у контексті якого в різних груп людей у певний момент часу виникає інтерес до природних та історико-культурних пам'яток тієї чи іншої території (своєрідний запуск механізму просторово-часової самоорганізації).

По мірі поширення інформації про ці пам'ятки i рівень обслуговування збільшується потік туристів, з'являються нові інфраструктурні об’єкти. У масовій свідомості фіксується установка, що туристично-рекреаційні ресурси району є унікальними. На нашу думку, цей момент асоціюється з точкою біфуркації, проходження якої означає незворотну трансформацію території у туристично-рекреаційний район - складний адміністративногосподарський організм, в якому сфера туризму i рекреації виступає системоформуючою компонентою для розвитку сільськогосподарських, транспортних, торговельних, культурнопобутових та інших організацій, сумісна діяльність яких дозволяє досягти ефекту мультиплікативності.

У точці біфуркації перед системою відкривається безліч шляхів еволюції і здійснюється вибір атрактора, в ролі якого виступають туристично-рекреаційні ресурси. На нашу думку, у сфері рекреації й туризму спостерігається своєрідна конкуренція атракторів: один 3 них асоціюється 3 уніфікацією туристичних 
продуктів під впливом вирівнювання показників рекреаційного споживання і туристських запитів в умовах глобалізації туристичного ринку, тоді як інший пов'язаний з подальшою диференціацією потреб, інтересів, цінностей і мотивів людей у сфері відпочинку, дозвілля, подорожей, а також диверсифікованістю підходів до рекреаційного районування і формування стратегій розвитку туризму.

Після проходження точки біфуркації стрімко збільшуються інвестиції у розвиток району, має місце приплив робочої сили, в результаті чого відбувається поступова асиміляція місцевих мешканців в їх середовищі, що нерідко призводить до втрати місцевої культури та формування нової. Далі йдуть незворотні екологічні зміни, через що регіон втрачає свою атрактивність [8, с. 33-34]. На цьому етапі, вочевидь, у системі наростає ентропія, що проявляється у збільшенні навантаження на природне середовище, рекреаційній дигресії, а також загрозах національній самобутності у зв'язку з нав'язуванням чужорідних культурних цінностей і поступовою втратою етнічної ідентичності. Перевищення критично допустимого рекреаційного навантаження території у зв’язку 3 відсутністю контролю за чисельністю відпочиваючих може призвести до негативної синергії, що означає не лише відсутність ефекту відновлення сил, але й накопичення негативних емоцій, переживання стресових ситуацій (потенційну шкоду для здоров'я людей), а також збитки для суб'єктів господарської діяльності.

Протилежною щодо ентропії тенденцією $€$ «негентропійне живлення» системи, що дозволяє досягти інформаційної упорядкованості та, відповідно, змінити ступінь ії розмаїття, складності і динамічності. Інструментами подолання наростаючої «екологічної ентропії» можуть вважатися заходи з рекреаційного природокористування, функціональне зонування рекреаційних територій, раціональна просторово-територіальна організація рекреаційних закладів тощо. Водночас, для протидії «соціальнокультурній ентропії» доцільно дбати про збереження культурної 
самобутності народів i підвищення якості туристичного продукту.

На нашу думку, для управління туристично-рекреаційною системою доцільно застосовувати синергетичну модель, провідним елементом якої $є$ інформаційна структура, що охоплює сукупність каналів масової комунікації, інформаційних технологій, взаємопов'язаних організаційних правил збирання і використання інформації. Так, 3 негентропійним упорядкуванням системи пов'язане рекреаційне районування - «послідовний процес просторового впорядкування інформації, що дозволяє комплексно оцінити особливості розміщення досліджуваних явищ і об'єктів та їх територіальної організації» [9]. У результаті прояву самоорганізаційних властивостей система генерує синергетичний потенціал, здатний через пошук множини чинників впливу i нестабільних станів вивести іï на траєкторію сталого розвитку [10, с. 51].

Таким чином, застосування синергетичної методології управління націлюватиме на пошук інноваційних методів задоволення туристських i рекреаційних потреб, підвищення адаптивності туристичного продукту до змін ринкової кон'юнктури, а також збільшення соціо-еколого-економічної ефективності функціонування сфери туризму і рекреації.

\section{Лiтература:}

1. Макара О.В., Гарасюк Д.М. Теоретичні основи формування територіальних туристично-рекреаційних систем. Науковий вісник Полтавського університету економіки $і$ торгівлі. Серія “Економічні науки”. 2014. № 2. C. 53-58.

2. Мармуль Л.О. Визначення ефективності функціонування рекреаційних підприємств та відтворення їх ресурсів на засадах системно-структурного аналізу і синтезу. Агросвіт. 2019. № 11. С. 10-15.

3. Благун I.C., Гонак I.M. Концептуальні основи формування територіальної рекреаційної системи. Вісник Чернівецького торговельно-економічного інституту. Серія “Економічні науки”. 2014. Вип. 4. С. 86-96.

4. Дегтярьова І.Б., Мельник О.І., Бондар А.В. Синергетичні ефекти еколого-економічних систем в умовах інформаційної економіки. Механізм регулювання економіки. 2013. № 3. С. 30-37. 
5. Якімцов В. Методологічні аспекти синергетичного дослідження соціоеколого-економічних систем. Економічний дискурс. 2018. Вип. 3. С. 123-134.

6. Загорський В.С. Концептуальні основи формування системи управління сталим розвитком еколого-економічних систем : монографія. Львів : ЛРІДУ НАДУ, 2018. $336 \mathrm{c.}$

7. Якімцов В.В. Теоретико-методологічні засади синергетичної ефективності функціонування складних соціо-еколого-економічних систем: автореф. дис. ... докт. екон. наук: 08.00.06; Львівський національний аграрний університет. Львів, 2019. 42 с.

8. Чир Н.В. Рекреаційна географія: навчально-методичний посібник. Мукачево : вид-во Дишкант С.Я., 2019. 156 с.

9. Гайда Ю.І., Ілюк В.І. Туристично-рекреаційне районування України: емпірично-статистичний підхід. Ефективна економіка. 2020. № 2. URL: http://www.economy.nayka.com.ua/?op=1\&z=7645 (дата звернення: 09.04.2021).

10. Лисенко Ю.В. Синергетика сталого розвитку галузей промисловості України. Причорноморські економічні студіï. 2017. Вип. 13-1. С. 48-52. 